\title{
The Possibility of a Scientific Approach to Analytic Theology
}

\author{
Andrew Torrance \\ University of St Andrews
}

\begin{abstract}
A question that is often asked of analytic theologians is: what, if anything, distinguishes analytic theology from philosophy of religion? In this essay, I consider two approaches to what is called "analytic theology." I argue that the first approach, which I associate with the common practice of analytic theology in the university, is very difficult to distinguish consistently from philosophy of religion. I also argue, however, that there is another approach that can be more clearly distinguished from philosophy of religion (generally understood). Following Aquinas, I associate this with a scientific approach to analytic theology: an approach that is distinguished by a specific commitment to understanding the mind-independent reality of God and all things in relation to God. The primary aim of this essay is to present an account of this latter approach and ask whether it might be possible to take such an approach in the contemporary university.
\end{abstract}

There is a wide range of views about what precisely constitutes analytic theology. While there is general agreement that it is characterized by such virtues as "logical rigour, clarity, and parsimony of expression" (Crisp 2009, 19; see also McCall 2015, 17; Rea 2009, 5-6), there is a reluctance to establish too narrow a definition of analytic theology-one that may end up excluding too many voices from the conversation it seeks to create. In this respect, it is like every other area of theology; its precise nature is hard to pin down. Consequently, there is a diversity of approaches taking place within this conversation. On the one hand, some work in analytic theology resembles that being undertaken by systematic theologians. On the other hand, some looks a lot like work being undertaken in the name of analytic philosophy of religion. This invites a common question: "What distinguishes (or does not distinguish) analytic theology from systematic theology, on the one hand, and philosophy of religion, on the other?" The situation is further complicated by the fact that there is a diversity of views as to how to answer this question. ${ }^{1}$ Without rehearsing these, let me offer a couple of short responses by way of introduction.

On the one hand, analytic theology can be distinguished from systematic theology by its recognition that philosophers in the analytic tradition have a

\footnotetext{
${ }^{1}$ See, for example, William Abraham 2009 and 2013; Max Baker-Hytch 2016; Oliver Crisp 2017; Alvin Plantinga 1992; Eleonore Stump 2013; and Nicholas Wolterstorff 2009.
}

Journal of Analytic Theology, Vol. 7, June 2019

10.12978/jat.2019-7.001322191404

(C) 2019 Andrew Torrance • (C) 2019 Journal of Analytic Theology 
constructive contribution to make at the theological table. Having said that, it is not clear why analytic philosophy cannot have this role in systematic theology; consequently, it is not entirely clear why there is a need to draw a sharp distinction between analytic and systematic theology. Yet there has been a lack of interaction between systematic theologians and analytic philosophers, and so the analytic theology movement addresses this by facilitating a conversation in which this interaction is encouraged. Within this conversation, the theologian recognizes that her theological reflection is accountable, in various ways, to critical questioning by analytic philosophers. Moreover, not only is she open to critical engagement from such quarters, she actively seeks such engagement because she believes it is of service to the theological task. This is not because she thinks that analytic argumentation will "establish or create faith," as James Arcadi notes, but because she thinks that it can "enable one who already believes the articles of faith to do so with greater confidence and clarity" (2017, 40). How, more precisely, the relationship between analytic philosophy and theology should be construed requires its own discussion-one that is beyond the scope of this essay.

On the other hand, how might we distinguish analytic theology from philosophy of religion? I argue that if we are to recognize that there is something distinctive about the nature of theology, there are good reasons to draw a sharper distinction between these two disciplines. However, as I will show, in the academic context there are understandable reasons why drawing too sharp a distinction can be problematic. Nonetheless, I shall also contend that, even in the university, there are ways to appreciate the uniqueness of the theological task; and I shall argue that the uniqueness of analytic theology lies in what I shall refer to as a commitment to being "scientific."

Now, clearly, the term "scientific" is a loaded term and, in our contemporary culture, tends to be associated with a naturalistic methodology. ${ }^{2}$ For the purposes of this essay, however, I shall follow Aquinas and use this term as it has been used throughout the history of theology-as scientia. Used in this way, it refers to theology as an endeavor to understand a mind-independent object in a way that is true to the nature of that object. As Karl Barth puts it, to be scientific is to be "thrown up against reality" with an "unconditional respect for the uniqueness of its chosen theme" (1922, 515). So when the term is applied to theology, it serves to acknowledge that the task of theology should be characterized by a commitment to understanding God and all things in relation to God (GATRG) in a way that is accountable to the true nature of GATRG (see Aquinas 2006, I.1.7) and takes into account God's self-disclosure.

Scientific Analytic Theology: an approach to analytic theology in which the theologian is expected to approach and give an account of GATRG in a way that seeks to correspond to or track the reality of GATRG.

\footnotetext{
${ }^{2}$ For this reason, some people might prefer me to use a different term--one that does not tend to be associated with the empirical scientific method of the natural sciences. However, my deep appreciation for the rich heritage that this term has had in the theological tradition means that I prefer to use this term. Nonetheless, I recognize that others might prefer to use a different term such as "theoscientific." Another possibility would be to talk about a theological approach to theology, which could be associated with what John Webster refers to as "theological theology (2005, 11-32; see also 2015).
} 
By being scientific in this way, the Christian analytic theologian aligns herself with the many theologians whose approach can be defined in these terms, including those who have explicitly viewed the task of theology as the scientific study of GATRG: including Thomas Aquinas, Bonaventure, Frances Turretin, Karl Barth, T.F. Torrance, and John Webster. With this commitment, the Christian analytic theologian follows the advice of Tom McCall who notes that "the task of the theologian is not merely to say things about God (or God-and-everything) - it is to speak truly of God (so far as we can) and to do so in a way that celebrates the glory of God's being and actions" $(2015,170)$ Furthermore, the Christian analytic theologian acknowledges Nicholas Wolterstorff's call upon theologians to study "how things look when seen in the light of the triune God-may his name be praised!-who creates and sustains us, who redeems us, and who will bring this frail and fallen, though yet glorious, humanity and cosmos to consummation" $(2005,91-92)$. As Oliver Crisp notes, these words from Wolterstorff "are surely words to live by." Crisp then adds: "Let us pursue our theologizing . . . to the greater glory of God" $(2017,165)$.

Before proceeding to discuss the scientific nature of analytic theology, it is relevant to clarify the place of theology amongst the plurality of voices that characterize the contemporary university-a community that (to varying extents and in various ways) recognizes a place for "freedom of academic expression." So, in the first section of this paper, I shall consider the objection that to describe analytic theology as "scientific," in the way that I am doing, risks tying it to a form of exclusivism that, while appropriate in some seminary contexts, would be inappropriate in the university. So, to tread cautiously, I acknowledge that there are at least two ways to think about what we call "theology": one that is more generic and one that is more concrete-with the latter being distinguished by its scientific character. What I shall also note is that the more generic understanding of analytic theology is not so easily distinguished from philosophy of religion. On this point, one of the things I aim to do in this essay is communicate that while it may be possible to define analytic theology in (at least) these two different ways, it is also important to avoid confusing these two versions of analytic theology, lest our understanding "GATRG" be domesticated by the prevailing ideology of a university. If these two versions are confused, then the reality of GATRG (the object of scientific theology) risks being reduced to a mind-dependent object of philosophy of religion-to human thoughts about GATRG (which is often the object of the kind of theology we find in the university).

At the same time, I shall also try to think about how we might recognize a place for scientific theology within university departments of theology that are expected to conform to a more generic definition of theology. In keeping with the university's commitment to diversity and inclusion, I shall go on to argue that being true to one's faith commitments might be a critical part of the analytic theological task; indeed, I shall argue that if a person is to take a scientific approach to analytic theology, this is essential. In so doing I shall advocate an approach that is likely to clash with some academic commitments to diplomacy in the study of religion-approaches that tend to disregard the theological conviction that characterizes orthodox religious belief. 
The somewhat divergent nature of my approach will become apparent in some of the more radical claims I propose in later sections. The radicality of these claims will correlate to my argument that if analytic theology is to be decisively distinguished from philosophy of religion, it will need to seek to be scientific, in the theological sense. To consider what a scientific approach might look like, the final section of this essay shall propose some distinguishing features of a Christian's scientific approach to analytic theology.

I shall conclude by acknowledging that the religious believer who teaches theology in the modern university may well need to approach analytic theology in a way that makes it indistinguishable from philosophy of religion. If so, however, she can recognize that there may well need to be more to the task of analytic theology as it is free to operate outside the ideological boundaries of her university setting-as it is free to seek to understand GATRG in a way that more fully conforms to the reality of GATRG.

\section{Theology in the University}

In universities that continue to have a place for the academic study of theology, theology tends to be treated as something like the study of a system of beliefs to which religious minds assent or have assented in the past. Generally speaking, and speaking descriptively, its mode in the university is loosely distinguished from religious studies, which tends to take a more detached sociological approach, focusing on making observations about the genealogy, history, practices, and artifacts of religious communities. One could say that theology looks more like a blend of religious studies and philosophy of religion (if we are to separate these two disciplines), insofar as it pays more attention to the nature, content, and structure of religious thought. At the same time, in the university, it is difficult to draw a hard and fast distinction between theology and religious studies or philosophy of religion, and there is unlikely to be any pressure to do so.

Within the university, the religious beliefs that the theologian studies can be associated with a wide range of religious traditions. There can be Hindu, Islamic, Jewish, and Christian theology; there may even be non-theistic theology such as Buddhist theology and, indeed, classes that explore agnostic and atheistic beliefs in the name of theology. So the theology student will find that, according to the university, the term "theology" is not tied to a specific religious tradition-to the extent that theology students may have the chance to study the theologies of a plurality of religious traditions. On a related note, if a student decides to undertake a theology degree at university, she will find that there is no expectation for her to have a specific religious commitment.

Under these circumstances "theology" is not strictly committed to understanding GATRG. Rather, it seeks to understand something like: (1) an absolute telos (usually a transcendent being such as God or, increasingly, whatever is the subject-matter of "spirituality"), as it is perceived by and gives shape to a specific religious tradition; and (2) the different stories, philosophies, worldviews, and 
teleologies that emerge when communities grow according to what they perceive to be their absolute telos.

This more generic understanding of theology is given careful consideration by William Wood, who has done some of the finest work on defining the task of analytic theology. Wood connects analytic theology with a philosophical theology that "makes no appeals to authority or to private revelatory experiences to defends its claims" (2014, 597). He associates this philosophical theology with Alvin Plantinga who, when claiming that "it is rational to interpret the Bible by the light of faith," does not ground "the soundness of that claim ... in the Bible, or faith, or private revelatory experiences, but in general philosophical arguments, available to all, about the nature of rational belief" $(2014,597)$. In a later article, he goes on to refer to this approach more specifically as the formal model of analytic theology. According to this model, Wood writes,

a theologian does not need to adhere to any substantive theological or philosophical views in order to count as an analytic theologian. She only needs to explicate whatever substantive views she does hold using the tools and methods of analytic philosophy. $(2016,255)$

At the same time, Wood also recognizes another model of analytic theology that "describes a substantive theological program". On this model, theology

draws on the tools and methods of analytic philosophy to advance a specific theological agenda, one that is, broadly speaking, associated with traditional Christian orthodoxy. On this conception, the central task of analytic theology is to develop philosophically well-grounded accounts of traditional Christian doctrines like the Trinity, Christology, and the atonement. For the most part, analytic theologians address these doctrines not from any specific confessional or ecclesial standpoint, but from a position that aims to be broadly orthodox. To be sure, some analytic theologians avowedly do write from within a confessional tradition. Nevertheless, because their work is usually grounded in philosophical arguments that are in principle accessible to all, rather than in appeals to narrowly confessional authority, their theology bids for cross-confessional interest. $(2016,255)$

While this model may be more substantive, Wood does not tie this model to a person's specific religious commitments. On this understanding, it would be no less theological for an atheist "to develop philosophically well-grounded accounts of traditional Christian doctrines" $(2016,255)$ than it would be for a Christian to do so. This is because, for Wood, a person's own theological commitments cannot be considered to be relevant to whether she can participate in a substantive theological program.

This does not mean that there won't be subjective differences between the respective agendas that drive different religious/non-religious believers in the study of theology. This is inevitable. Suppose, for example, that a Christian and an atheist are both taking a course on the doctrine of the Trinity. Whereas a Christian is likely 
to undertake theological study in this area for the sake of learning about GATRG, the atheist will be likely to pursue such study for the sake of understanding the Christian understanding of GATRG. However, according to the judgement of the university, the question of whether or not a theological position actually corresponds to GATRG (i.e., whether it is scientific) is beside the point. This is because the university does not judge accountability to God as a virtue to which any of its scholars (even its theologians) should aspire.

So, it is not hard to see why the university context is going to be awkward for the task of something called "theology." Indeed, there is good reason to think that it makes more sense to associate the atheist's approach to theology with such disciplines as philosophy of religion, history, sociology, religious studies, or, as I consider below, "atheology." Why? Because, clearly, the atheist's study (-logia) has nothing to do with God (Theos). The atheist focuses her attention on studying (what she perceives to be) the creative imaginings of the theist. At the same time, this does not mean that an atheist's work cannot be seen to contribute to the theist's endeavor to understand GATRG. For example, there is no reason why an atheist could not write a book on the doctrine of the Trinity that the Christian could interpret as a piece of good theology, despite the fact that the atheist does not think her work has anything to do with the triune God (whom she believes to be nothing more than an unwarranted projection of the Christian imagination). It should be noted, of course, that the ability of such a book to serve Christian thought cannot be relevant to whether an academic scholar judges it to be a good piece of theology according to the criteria of the university.

Under these circumstances, theologians appear to be obliged to recognize that much of what the university views as theology could also be described as philosophy of religion, history, sociology, or religious studies. Indeed, most theologians accept this (at least functionally). A quick scan through any number of leading academic journals will show that a great deal of systematic and modern theology focuses on the history of theological ideas (such as those of Augustine, Aquinas, Calvin, etc.); a great deal of practical theology looks a lot like sociology of religion; and a great deal of analytic theology looks a lot like philosophy of religion. While such work may not directly serve to develop our knowledge of GATRG, there is no question that a Christian can draw upon it to serve this purpose. Throughout the life of the Church, the history of theological investigation, the analysis of religious communities, and the philosophical study of religious ideas have all been drawn upon to serve the study of GATRG. Moreover, if there were no place for this kind of scholarship, it is hard to know how the discipline that Christians call "theology" could exist.

While it may be possible for the university to have a more generic approach to theology, which is not tied to the study of GATRG, this does not mean that there are not valid reasons why religious believers might not want scholars from other religious or non-religious persuasions to teach theology in their seminary context. For example, Muslims are likely to think that the religious commitments of an Islamic professor will make her more committed to providing a true presentation of Allah than a Christian professor would. For this reason, most Islamic seminaries will exclude Christians from teaching in their theological programs-just as most 
Christian seminaries will exclude Muslims from teaching in their theological programs.

At the same time, there are also good reasons why religious thinkers might be happy for the discipline of theology to be defined more generally in a way that allows safe harbor for a plurality of (1) conversation partners, (2) religious/non-religious affiliations, and (3) disciplinary interests-as is the case in the university. Whatever the religious/non-religious tradition with which one associates theology, there can be a recognition that the theological world is greatly diminished if: (1) it refuses to listen to the voices of those outside one's own particular religious tradition; (2) it refuses to recognize that there are other religious traditions whose adherents are sincerely committed to knowing the truth; and (3) it seeks to ignore the historical, cultural, social, philosophical, natural scientific, and other work that is being undertaken and which makes no reference to God. By disregarding the plurality of voices that make up the world at large, theology will become characterized by an isolationism that will undermine its capacity to engage with the world as it is. Furthermore, it will also fail to ask of its own commitments and suppositions the kinds of questions that such engagement generates.

This raises the key question: if theology takes on the identity that the university imposes on it, why distinguish the task of theology from the philosophy of religion, religious studies, or history of religious thought when it is undertaken in the context of the university? As I consider below, there are good reasons for universities to allow room for a discipline wherein persons can seek to know GATRG in a way that corresponds to their respective beliefs. Again, this is what I call scientific theology because of its commitment to being true to the mind-independent object (or subject) of theology (God), in a way that is accountable to the self-revelation of that object. Such a pursuit is a distinctively theological task that does not easily fall under the category "philosophy of religion." Why not? Because, for the vast majority of those who believe in God, religion is accountable to the living God; God is not merely a projection of human philosophy or religion. Consequently, the study of GATRG cannot simply be a thought-project undertaken independently of and in abstraction from any act of self-disclosure on God's part. The affirmations of the faithful theologian cannot be subject to the predeterminations of a thought-project that is operating with a foreign set of criteria. For her, theology cannot reject or bracket out the recognition of God's being, nature, and purposes, if it is to be committed to rigorous engagement with the questions at the heart of her respective theistic tradition.

Now, if there is to be a space within universities for religious believers to pursue scientific theology, they will be required to do so alongside persons who are pursuing "theology" in a different way and from different epistemic affiliations and commitments - a way that, from their theological perspective, may well seem more akin to philosophy of religion or religious studies. For some, this may generate discomfort or even confusion. But at the end of the day this is a bullet that they will need to bite if they are to enjoy the many benefits that come from pursuing the theological task in the context of the plural affiliations and commitments that define the contemporary university. While such a context may again seem like a strange habitat for theological endeavor, it is worth noting that the strangeness of this habitat conforms to the strangeness of the world in which the theologian lives-in which the 
theologian is not simply called to preach to the choir but is also called to be (what may be to others) a voice crying in the wilderness (as those other voices may also seem from the perspective of the faithful theologian).

\section{Scientific Analytic Theology}

Before elaborating on how I construe the scientific nature of analytic theology, let me begin by addressing a possible retort to the suggestion that analytic theology can be scientific. Being scientific requires synthetic reasoning, which, according to the analytic/synthetic distinction (as we find in Kant, for example), is to be distinguished from analytic reasoning. In response to this, let me make this brief point: if the "analytic" of analytic theology is the "analytic" of the traditional analytic/synthetic distinction, then there is no possibility of a Christian analytic theology. Christian analytic theology must be shaped continuously by the historically and empirically formed propositions of Scripture and the Church. The truth of theological propositions cannot ultimately be assessed by simply exploring the meanings of the constituent terms. Rather, theological affirmations are true according to the truthfulness of their witness to God's self-disclosure to the contingent order in spacetime. They are known, therefore, by non-deductive a posteriori means.

What, then, do I mean by a scientific approach to theology? As I noted in the introduction, scientific theology is committed to understanding GATRG in a way that is accountable to the true nature of GATRG. It does not interpret God in merely subjective terms, as a human projection: a human belief, conceptual postulate, social construct, character in a story, etc. Rather, it seeks to bear witness to the mindindependent reality of God-the living God to whom the true account of GATRG must correspond and can do so because of God's self-disclosure.

Now, in endorsing a scientific approach to analytic theology, an accompanying commitment to transparency requires me to be open about the fact that I am a Christian. This is because I believe that the task of referring truly to GATRG requires me to speak Christianly. This will necessarily have an impact on the way I approach the topic of this paper (particularly in what follows). If I am to approach the theological task scientifically, I must recognize the way in which my own faith makes a decisive difference to how I understand the true nature of GATRG.

As a Christian theologian, I understand that the true and proper object of scientific theology is: (1) the triune God, according to God's self-revelation; and (2) creation, according to what God reveals creation to be before God. These things are known according to God's revelation in and through history as it is attested to in the Biblical witness, the creeds, and the intellectual history of the Church. While my attention could be given to a broad range of matters concerning GATRG, the central focus of my attention is the one who most fully reveals (1) and (2): the creative Dabar become flesh, the one through whom and for whom all things were created, the sole living mediator between God and humankind, the risen and ascended Jesus Christ. Accordingly, as I shall discuss further below, I also understand that my judgement must be shaped and informed by the kinds of activity that correspond to the life of the 
Church, the "body of Christ". That is, theology must not simply be undertaken in service of the Church; it must also grow out of and be sustained by the one true Lord who is the source of the life of the Church, and all its forms of speech, confession, and faithful God-talk.

In short, as a Christian, I understand that the scientific task of the analytic theologian must be to employ her analytic skills in the service of witness to God's selfdisclosure as Word or Logos, in the person of Jesus Christ. As such, any commitment to argumentative rigor, clarity, and precision should only be recognized as valuable insofar as it helps the Church to offer a fresh, faithful, and disciplined witness to God's self-disclosure as incarnate Logos. What this means more precisely will be discussed in the penultimate section of this essay.

It is not hard to see why such an approach to theology could be dismissed as conveying, if not endorsing, an exclusively Christian form of theological arrogance. And, in the context of the university, such a criticism is likely to be particularly pointed. This is because, again, the university theologian is (normally) expected to recognize and, indeed, respect the fact that there can be a plurality of views about what informs the task of theology, depending on who or what a person thinks the object denoted as "god" might be. Hence, we are presented with an obvious challenge: how can a religious believer take a scientific approach to theology in a way that aligns with the university's respect for diversity? The answer is clear. A genuine respect for diversity requires the university to respect the real differences that distinguish religious believers-differences that entail a commitment to beliefs that are incompatible with the religious beliefs of other religious and non-religious traditions.

\section{Scientific Theology among Religious and Non-Religious Traditions}

So, what is required if the university is to provide a safe place for an open and diverse conversation about theology? Does it require theology never to be tied to a particular religious (or ideological or philosophical) tradition?

The first thing to note is that, if a theology department is to be genuinely open to engaging with a diversity of religious and non-religious traditions, it cannot presuppose any particular dogma or "-ism.." Clearly, this refers not only to religious commitments but also to the dogmas of atheistic secularism and naturalism, which are too often mistaken to be "neutral" or "objective." It also refers to the influential dogmas of inclusivism, relativism, and pluralism, which are sometimes mistaken to be essentially inclusive (see Plantinga 1997, 2000). Given that the university is obliged to treat most truth-claims as provisional (so as to invite falsification), the university should be open to diverse approaches to the theological task, and this will require scholars to recognize the mutual exclusivity of their divergent epistemic

\footnotetext{
${ }^{3}$ The Latin "universitas" means "whole." So, if it is in keeping with its Latin root, the university should strive to represent the "whole"-of which secular thought is a minority in the world and history of thought.
} 
bases. To take the above seriously and not fall prey to the prevailing "-ism" of a particular academic culture, theology departments should allow theologians to make exclusive truth claims about GATRG in their particular study of GATRG. If the university does not welcome such an approach, then it is, in effect, requiring academics, who operate from a particular epistemic base, to disguise or conceal what they recognize to be true and thereby deny or compromise their intellectual integrity.

But does this not open the door to and, thereby, give credibility to every kind of fideistic affiliation? Not if there are criteria for determining whether a particular theological approach is fit to engage in academic research in a particular university. Although an analysis of what criteria might count would require an essay of its own, I would suggest that criteria should include: explanatory power; a demonstrable relevance to social flourishing; an openness to rigorous, pellucid, and transparent argumentation; and an importance for understanding the (past, present, and future) functioning of society. Even the most secular of thinkers are likely to acknowledge that-although they may not endorse belief in God-theological belief has had and continues to have a profound impact on the history, culture, and intellectual commitments of contemporary society-on principles of liberal democracy, for example. This being so, they should hopefully be open to (what they will regard as) an in-depth religious phenomenology which, given the very nature of the situation, requires particular traditions to be explored in ways that take seriously the foundational beliefs that constitute those traditions. For religious believers themselves, there should be no question about the value of a scientific approach to theology, since theological convictions are foundational to their perception of reality - to their understanding of the ultimate nature of all things.

If academics are required to take a step back from the task of theology and engage in nothing more than a philosophical analysis of generic religious claims or a sociological study of religious believers, they risk removing themselves from rigorous engagement with religious commitments. An exclusive or absolute commitment to a quasi-neutral (or pseudo-neutral) academic base, which will inevitably be reductionistic, will displace the possibility of the kind of conversation that engages authentically with the inner workings and convictions of the religious mind.

The thrust of my argument here is that the university's commitment to the pursuit of understanding is profoundly undermined if it is tied "religiously" to a single, predetermined, and intrinsically areligious agenda. This does not mean that the religious believer cannot respect the areligious thinker's freedom to take an areligious approach within the university (among the plurality of approaches). Nor does it mean, of course, that the areligious thinker will be unable to draw many of the same conclusions as religious believers. Indeed, I expect that areligious and religious thinkers, who work together within the university, will find that it is perfectly normal for their conclusions to be held by persons from various religious and non-religious traditions (even when doing theology). Nonetheless, it is also not hard to recognize that there is a major lacuna in the university if it does not allow religious believers to adopt a scientific approach to analytic theology. As we have seen, such a lacuna can be recognized as such on the basis of academic commitments that are secular or theological. 
What, then, does it look like for scientific theology to be undertaken within a plural academic context? The Christian, for example, would have no option but to think that the true and faithful study of GATRG should operate from a Christian epistemic base and that she should take up her task accordingly. This does not mean, however, that the Christian should expect non-Christian Jews or Muslims, for example, to approach the theological task in the same way that she does. Quite the contrary: the Christian should expect them to pursue the scientific task of theology in a way that is true to their belief in GATRG. The Christian, of course, will continue to think that they are deeply mistaken about how to approach the task of theology scientifically. At the same time, the Christian is obliged to respect the fact that they will think that she is deeply mistaken in this regard. She will continue to think that scientific theology is tied to the triune God, and they will think that scientific theology is subverted by taking into account what she regards as the essential condition for the recognition of what she knows.

What I am proposing here is that the university theology department should be a space that is open to the possibility of open and mutual disagreement about what theology is. Again, therefore, it should not be so committed to an areligious agenda that it rules out any room for the religious voice. It should allow for and, indeed, facilitate a diverse conversation in which participants can articulate their theological positions humbly and respectfully yet with conviction and honesty. If, by contrast, theists of differing views are expected to assume an equivalency to the various ways in which each of them talks about GATRG, then they will be required to conditionalize on the basis of a theological view that they have no option but to assume to be false. What this effectively conveys is the endorsement of a form of theological relativism: the assumption that when we speak "truly" about GATRG in the university, GATRG should be interpreted as relative to our own subjective perspectives. Such an approach would require the vast majority of theists to commit to talking about God in a way that was no longer accountable to the reality they purport to confess. Put simply, they would be obliged to commit to a form of anti-realism which, if not selfreferentially incoherent, would be incompatible with their most deeply held convictions. It would oblige them to assume a disingenuous stance.

Does the position I am proposing entail that there are no areas in theology where Christians can share in a constructive scientific theological conversation with non-Christian Jews and Muslims about the God of Abraham? While I cannot devote due attention to this question here, I believe this is possible to the extent that Christians, non-Christian Jews, and Muslims are referring to the same God, namely, the God who revealed Godself to Abraham. However, I am also of the view that if such a conversation were to take place, the Christian, non-Christian Jew, and Muslim should judge the theological fruitfulness or success of this conversation according to their own respective commitments. Clearly, for example, they would have to acknowledge that they do not all share a belief in the incarnation or the triune nature of God, which are decisive to the Christian's understanding of GATRG.

What about atheists? The position for which I am arguing entails that it does not make sense to refer to atheists as adopting a scientific approach to theology. If someone does not think there is a God to talk about, then it is hard to conceive of how such a person can think it is valid to construe theology as a scientific enterprise. As I 
discussed above, she may be committed to studying the beliefs that others have about God. Such a pursuit may well be described as "scientific" in a social-scientific sense. However, insofar as the atheist is not committed to a scientific pursuit of GATRG, it does not make sense to suggest that she is dedicated to a scientific approach to theology. If the atheist wants to take a more scientific approach to questions relating to theology (or metaphysics), it would make more sense for her to see herself as being committed to a task of scientific atheology: a commitment to studying (what she perceives to be) the nature of reality according to the belief that God does not exist.

Let me conclude this section by emphasizing that this position does not in any way suggest that religious believers should have permission to be less respectful to those who are outside their religious tradition within a university department of theology. Indeed, Christian convictions would require the opposite. The argument is, quite simply, that the university should have a place for theological educators to teach theology with intellectual integrity and thus in a way that is true to how they know GATRG. Again, however, when such an approach is adopted, it should be undertaken with transparency. That is, theological educators who approach their task scientifically should make clear the underlying premises to which they are committed, and which lead them to teach in the way that they do.

\section{A Note of Caution on Transparency}

While it is important for the scientific theologian to be transparent, there also needs to be a cautiousness about how one goes about being transparent. Imagine, for example, that an evolutionary biologist decided it was important, for the sake of transparency, to qualify that her particular evolutionary theory was based on her Christian understanding of developmental biology. Such a qualification would be likely to invite the suspicion that she was projecting her own religious views onto her theory in a way that undermined the scientific credibility of her research (even if this were not so). If, by contrast, she decided that, for the sake of transparency, it was important to qualify that her study was based on paleontological research done in Northern Africa, this would not be a problem. Why? Because, whereas paleontology can clearly be seen to have a positive role to play in her study, it is much harder to see how her Christian belief could have such a role-to the extent that openly drawing on her Christian understanding will be likely to lead her colleagues to call into question the validity of her methodology and the credibility of her conclusions.

Now, suppose that a scientific theologian decided it was important, for the sake of transparency, to suggest that her claim that Jesus was the Son of God reflected her Christian worldview. Such a qualification could risk inviting the perception that she is projecting her own subjective religious beliefs onto her understanding of the historical Jesus in a way that skewed the scientific nature of her study. Such a perception, however, would not be true to the Christian's understanding. For the Christian, faithful understanding does not merely have a positive role to play in a scientific approach to theology, it is necessary for such an approach; without the condition that is described as "faith," she has no recognition of GATRG. To be clear, 
this is not because the reality of the triune God is grounded in a person's faithful perception. Rather, it is because it is by God actively delivering persons into a faithful knowledge of God that God makes Godself known. And just as the life scientist needs to interact with the revelatory activity of the living world, so also the theological scientist needs to engage with the revelatory activity of the living God. In Christian theological terms, this takes place by way of the risen and ascended Christ sending the Holy Spirit to facilitate that form of recognition that is constitutive of the epistemic foundations of the Church-the knowledge that is constitutive of its existence. Clearly, there is much more to be said here. Suffice it to say, there is little question that a central commitment of Christian orthodoxy is the belief that it is not simply the faith of the Christian that is foundational to the confession that Jesus is the Son of God; rather, it is the living Jesus Christ who is foundational to the faith by means of which the Christian confesses that Jesus is the Son of God. This is the sine qua non of scientific engagement with its subject-matter on the part of the Christian theologian. What this entails is that if Jesus is not the Son of God, then a Christian approach to theology is not, in actual fact, scientific; it is merely, as Athanasius saw so clearly, the mythical projections of a deluded scholar who fails to appreciate that the object of her academic engagement is non-existent.

What should be clear is that for the Christian who is committed to the task of scientific theology, it is almost tautologous to endorse a Christian approach to scientific theology. Why? Because, for the Christian, the truest study of GATRG is inevitably Christian. It is not open to her to select from a variety of foreign religious approaches how best to study GATRG: Hindu theology, Buddhist theology, Islamic theology, or even non-Christian Jewish theology, etc. The only scientific way for the Christian to approach the task of scientific theology is to be faithful to the one mediator between God and humankind, Jesus Christ, the one who is known to be foundational to the mind of the Church (as articulated in and through the biblical canon, creeds, confessions, and the prayerful community in which she participates).

\section{A Christian Approach to Scientific Analytic Theology}

I have argued in this paper that it is possible for analytic theology to be distinguished from philosophy of religion by allowing for the possibility of a scientific approach to theology: allowing persons to participate in an analytic theological endeavor which seeks to be accountable to GATRG. By way of conclusion, I shall now propose how a Christian, who recognizes accountability to the triune God, might distinguish her scientific approach to analytic theology from a form of philosophy of religion.

As I mentioned above, it is central to the faith of the Church that God revealed Godself in history. This means that analytic theology cannot restrict its focus to meaning, value, or other categories cleansed from the irreducible particularity of historical phenomena. Instead, its task is bound up with God's historical selfdisclosure in the spatiotemporal order. For these reasons, a scientific approach to analytic theology cannot but be engaged with the central event of God's selfrevelation: the incarnation of Jesus Christ, the one in whom all things (all truth and 
reality) hold together-the one in whom, as Kierkegaard put it, the eternal has established kinship with us in time $(2003,573)$.

Now, for the analytic theologian who models her task on the analytic philosopher, a commitment to God's Word-and to the ordained words and dogma that attest to it-is thoroughly inconvenient. The messiness of the Canon of Scripture, the mysterious complexity of the Trinity, the paradoxicality of Christology are just some of the things that hold analytic theology back from being characterized by the same kind of rigor, clarity, precision, and transparency that characterizes analytic philosophy. Indeed, it may even be embarrassing for such a person to take up the task of analytic theology. This can make it enormously tempting for the analytic theologian to shirk her responsibility to God's Word and to the historical narrative at the heart of the faith. And herein lies the stumbling block for the analytic thinker who seeks to take a scientific approach to theology. There is a danger that, in order to embrace the virtues of analytic philosophy (as they are understood by the cultures of philosophy that are embedded in this present world), the analytic theologian distances herself from the historical and ecclesial foundations of the Christian faith, opting instead to give her attention to a generic God of philosophy-a deistic or Epicurean "god" who is necessarily removed from the exigencies of the spatiotemporal order, "residing" in a transcendent noumenal realm that is infinitely removed from human history.

When this happens, it is hard to see how analytic theology can be said to be anything more than a generic form of philosophy of religion. Once this step is made, it becomes all too easy for the analytic theologian to get on with the theological task in a way that is indifferent to God's engagement in and with the contingent order. Analytic philosophy of religion does not need to be (even if it can be) directed by the revelatory activity of God in the way that a scientific approach to theology must be. If this happens, there can be no scientific approach to the task of analytic theology, conceived as a Christian enterprise, and any real distinction between analytic theology and philosophy of religion becomes hard to draw.

That having been said, a glaring difficulty emerges with respect to what I have just said. In and of itself, the human task of theology does not possess the capacity to be anything more than a human venture. And because human language cannot directly represent God's Word or refer to the reality of God as such, the question arises as to how theology can ever be anything more than a form of human speculation. As a human venture, it would appear that it can do nothing more than talk about mere human thoughts about GATRG. If this is the case, then it must be kept in check by the strictures of human reason. This does not mean that scientific analytic theology can be reduced to a generic philosophy of religion, which focuses merely on the general religious ideas of human cultures. What it does mean, however, is that it is hard to distinguish a scientific analytic theology from Christian philosophy. How, then, can (or, indeed, why should) analytic theology claim to be anything more than a philosophical endeavor-a conversation about the human ideas that emerge within the Christian religion?

Let me first say that it is folly to suggest that the broader task of theology should not engage with philosophy-just as there is nothing wrong with seeing Church history, the history of ideas, psychology, sociology, etc. as disciplines that serve the task of theology. Again, it is not possible for us, as mere human beings, to 
talk directly about GATRG, unadulterated by attention to things that are not God or are not being discussed in relation to God. And when we undertake the task of theology, we are using the tools of philosophical reflection. Indeed, it may be that, within the life of the Church, there are no clear boundaries between the human task of Christian theology and that of Christian philosophy. In the eschaton, moreover, the domains and methods of philosophy and theology may be indistinguishable.

At the same time, it is also important to recognize that, as these two disciplines operate within the cultures of this world, they have distinctive audiences. Christian philosophy tends to be distinguished by its concern to talk Christianly within an embedded philosophical culture that has a more secular language, criteria, and set of commitments. This means that the Christian philosopher will need to think differently about how to communicate herself than will the theologian who is perhaps more likely to be engaging with an audience who is sympathetic to the truth of religion.

On a related note, given the character of philosophy and the domain that philosophers inhabit, Christian philosophy may be slightly more likely to treat GATRG as a self-contained conceptual system associated with GATRG-although I am not at all sure that such an approach is any rarer in the world of theology. Given the inability of human thinkers to engage in pure theology (to talk or think directly about GATRG), it is inevitable that human beings may withdraw into conversations that are essentially inattentive to the reality of GATRG (to the extent that this involves historical engagement with irreducibly historical realities).

In sharp contrast, the Apostle Paul saw the providence of God as essential to the task of theology. He insisted that those who seek to know God must bind themselves in prayer to the one mediator (1 Tim. 2:5), Jesus Christ, the only one in whom pure theology is possible for humanity-or, in the words of the writer of Hebrews, Jesus the "high priest of our confession" (Heb. 3:1). Paul also interpreted the coming of the Holy Spirit as essential to the Church's task of theology-for "no one comprehends what is truly God's except the Spirit of God" (1 Cor. 2:11). ${ }^{4}$ For Paul, it is because Jesus Christ sends the Holy Spirit to inspire the wisdom of the Church that it is possible for the Church to know God in a way that is true to its calling as God's kingdom come, on earth as it is heaven. So, for Paul, the theologian of the Church must seek to go about her task with the support of God's revelatory activity. It is in this way that the theologian can hope to be accountable to GATRG.

\section{Five Distinguishing Features of Christian Analytic Theology}

\footnotetext{
${ }^{4}$ To be clear, I would agree with William Abraham that persons should not appeal to the internal witness of the Holy Spirit to support their particular theological agenda, to the extent that this witness is treated "as the decisive and logically primitive warrant for one's position" $(1990,442)$. At the same time, I would also not want to deny that the witness of the Holy Spirit can help a person's judgement when it comes to making the right decisions about doctrinal matters. There is much more to be said here, but that would take us beyond the scope of this essay.
} 
With this in mind, let me propose five distinguishing features of Christian analytic theology if it is to be characterized as the scientific study of God. As I understand it, from a Christian perspective, each of these five features can be seen to serve the task of knowing God in a way that furthers a person's scientific theological judgement and understanding. At the same time, they would not be seen to be appropriate in a more generic approach to philosophy of religion (or in the more generic forms of theology that are indistinguishable from philosophy of religion).

First, the scientific analytic theologian sees her primary vocation as serving the task of proclamation. Because she has been addressed by the Word of God, she feels called to stand as a vocal witness to the historical events of God's revelation-a witness who can hope to succeed in her task by means of the illumination of the Holy Spirit. As this witness, she proclaims that the origin and pursuit of theology lie with the spirit of wisdom and revelation that is given by the Lord Jesus Christ (Eph. 1:17). Without the revelatory activity of God, a person cannot know the triune God and, therefore, cannot know the one to whom theological words refer-such words would take on a life of their own within a closed system of human thinking. Again, theology conceived accordingly could not be anything more than a generic form of philosophy of religion or religious studies. To be clear, however, the human theologian is never able to demonstrate directly that revelation is taking place in the midst of her conversation; that is, she can never demonstrate directly that God is present, actively associating theological talk with its object. Nonetheless, she can trust that this will happen to the extent that her proclamation of the Gospel is accompanied by the power of the Holy Spirit and is faithful to God's self-disclosure in and through the sole mediator. This is the givenness of the givingness of God's self-revelation. ${ }^{5}$ That is, it is by faith in the givenness of God's promise to keep giving Godself to be known, by the giving of the Holy Spirit, that the Christian finds the audacity to believe that she can serve as an effective witness to GATRG.

Second, as I have mentioned, scientific analytic theology can be more than philosophy of religion by being grounded in the life of the Church - the community that is sustained by God to be the visible and living testimony to God's self-revelation. Insofar as theology takes up the task of proclaiming God's Word, it does so within the domain of the Church. Therefore the past and ongoing witness of the Church must continually direct the task of theology. To be clear, in making this statement I am not suggesting that the task of theology must correspond to some abstract or past notion of "the Church." I mean that the life of the theologian must be energized and directed by an active involvement in the life of the Church today. If this does not happen, then the Christian theologian will be likely to forget who she is and lose sight of what she is doing.

\footnotetext{
5 There is an important difference between the "givenness of God's self-revelation" and "the givenness of the givingness of God's self-revelation". Whereas the former suggests that God's self-revelation has somehow been handed over to the world to appropriate in, for, and by itself, the latter suggests that God's self-revelation involves the continued giving of Godself to be known. It is by God's ongoing acts of self-communication that human minds can become attuned to the true content of revelation.
} 
Third, the analytic theologian will always be aware that she is in a predicament-one that requires humility. As she seeks to go about her task in this broken world, guided by a broken Church, she will be humbled by the fact that her apparent rigor, clarity, and precision may have been facilitated by guiding principles that do not correspond to the grace of God. The lack of confidence that the analytic theologian has in her own judgement means that she will constantly be returning to Scripture and to ecumenical statements to guide her. This will also move her to go about her task prayerfully and worshipfully, humbly paying as much attention (if not more attention) to the wisdom of the Church community as she does to the wisdom of her academic community.

Fourth, as I have also mentioned, the analytic theologian will forever be aware of the apparent awkwardness of her task. That is, her endeavor to be clear, precise, and rigorous in argument can appear to be hindered by her beholdenness to the unsystematic and complex nature of the biblical canon, to the exigencies of history, and to the human witness to it in the early ecumenical Church. Also, the analytic theologian will continually be held back by the unfathomable paradoxes that keep cropping up as she struggles to talk about things that lie beyond human comprehension, but which confront her nonetheless. Yet, she is not frustrated by these things. As she stands before God, this does not induce anxiety; it does not generate intellectual despair. It simply reminds her, once again, of the limits of the theological task, as these things attest to the horizon where human words end and God's Word begins. So, rather than despairing, she finds joy and hope in the fact that she is not called to go about her task alone. Instead, she seeks to do no more than take persons to the horizon of human words in an act of witness. She then proclaims the good news of the only one who unites us with the other side of that horizon-the one mediator, Jesus Christ, who supports and directs us in ways that cannot be achieved within our own systems of thought.

Fifth, not only does analytic theology have its proper grounding in the life of the Church, but it also recognizes that its calling is to serve the Church. As a technical and systematic discipline, it has the task of helping to bring rigor, clarity, precision, and transparency to the teaching of the Church (insofar as it can). But, again, this must always be a reciprocal relationship. As the analytic theologian seeks to bring clarity to the Church's teaching, she should expect to be questioned by the Church community in a way that will help her to become clearer, more precise, and more rigorous about her unique subject matter-all so that she may be ever truer to the theological task.

These five distinguishing features of analytic theology are bound together by the fact that the Christian analytic theologian recognizes that true talk about GATRG has no past, present, or future apart from the grace of God. As God sustains the analytic theologian in her task, she is sustained by an activity that cannot be commandeered by human reason-that cannot fit into one of her systematic doctrines or theories, and which cannot be submitted to the Procrustean bed of our "-isms" or "-ologies."

In sum, for the Christian, it is by recognizing the grace of God that the analytic theologian does not need to accept that her fate is to be what, on the surface, she directly appears to be: a thinker who is unable to study "God" as anything more than 
a mere religious idea. Also, by grace and by the recognition of grace, the analytic theologian not only needs to trust and hope in the possibility of a scientific approach to theology; she can know that this is possible. More specifically, if Paul's theological vision is accurate, then the analytic theologian is called to recognize that the study of GATRG has no future apart from the crucified, risen, and ascended Christ. To paraphrase Paul, if Christ has not been raised then both our proclamation and our faith is futile (1 Cor. 15:17). And if these things are futile, then so also is the task of theology. What is more, it is because Jesus Christ is alive today, sending the Holy Spirit, that the Church is maintained as the source of true theological understanding.

What, then, does it mean for the analytic theologian to take seriously the work of the Holy Spirit and Jesus Christ, the incarnate Logos? It means she will recognize that, ultimately, theological clarity comes with the Spirit giving the theologian the eyes to see and the ears to hear the one true Logos-the one true Word. True theological precision and reference come from directing attention to the one who mediates between God and humankind, and between humankind and God. Lastly, true theological transparency can only arise when the theologian's testimony is inspired by the work of the Holy Spirit-when those listening to the theologian come to know the one to whom she bears faithful witness-when their hearts and minds are given to recognize the one true Lord whom the Christian theologian has been given to know.

\section{Conclusion}

So, in light of what I have just said, what does it mean to pursue theological enquiry in the university? Clearly, in the context of the ideological plurality of many universities, the Christian analytic theologian may not be able to engage in all the kinds of activity that will best distinguish her task from philosophy of religion or Church history. Each Christian theologian will need to think carefully about how she can be accountable to GATRG according to the specific context and demands of her own university. While this essay has offered some guidance as to how one might think about these things, I would not be so bold as to set forth strict guidelines that apply to every academic context. Each university will have distinctive concerns and priorities that are formed by its engagement with its local context. And these must inform the theologian's decision as to how far or, indeed, whether she can adopt a scientific approach to theology. For example, in writing this essay, I have been informed by my own university's strong commitment to diversity and inclusionwhich the principal of the university describes as one of the "defining themes" of her principalship. Other academic contexts will prioritize a commitment to secularism over against diversity and inclusion. Or, indeed, in some countries, for example, a commitment to Islam may take priority. It should go without saying that contextual factors such as these will have an impact on how a religious believer should approach the academic task of analytic theology with wisdom. For these reasons, there may be contexts where that analytic theologian decides that it is not possible to pursue 
Christian analytic theology and so elects to engage in what would more accurately be described as philosophy of religion.

At the same time, if wisdom leads the analytic theologian to decide that some theological practices cannot be an appropriate part of theological education within a particular university, she may need to recognize that her academic context may not be the best environment in which to seek to understand GATRG. It will then be up to her to think about how her academic work in analytic theology/philosophy of religion can be resourced to serve a more scientific approach to analytic theology-that is, to the extent that it is free to operate beyond the ideological constraints of her particular academic context. It will also be up to her to think about how her practices outside her academic domain might inform how she understands the specific nature of her vocation within that domain. ${ }^{6}$

\footnotetext{
${ }^{6}$ I am grateful to the following persons for helpful feedback on an earlier version of this paper: Max Baker-Hytch, Joshua Cockayne, Oliver Crisp, C. Stephen Evans, Mitch Mallary, Christa McKirland, Philip-Neri Reese, Stephanie Nordby, Jonathan Rutledge, Alan Torrance, Koert Verhagen, Charlotte van Oyen-Witvliet, and William Wood. I am also grateful for the financial support of the Templeton Religion Trust.
} 


\section{Bibliography}

Abraham, William J. 1990. "The Epistemological Significance of the Inner Witness of the Holy Spirit." Faith and Philosophy 7: 434-50.

. 2009. "Systematic Theology as Analytic Theology." In Analytic Theology: New Essays in the Philosophy of Theology, edited by Oliver D. Crisp and Michael C. Rea. Oxford: Oxford University Press.

. 2013. "Turning Philosophical Water into Theological Wine." Journal of Analytic Theology 4: 347-61.

Aquinas, Thomas. 2006. Summa Theologiae Volume 1, edited and translated by Thomas Gilby. Cambridge University Press.

Arcadi, James. 2017. "Analytic Theology as Declarative Theology." Theologica 1: 3752.

Baker-Hytch, Max. 2016. "Analytic Theology and Analytic Philosophy of Religion: What's the Difference." Journal of Analytic Theology 1: 1-16.

Barth, Karl. 1922. Der Römerbrief (Zweite Fassung). Theologischer Verlag Zürich.

Crisp, Oliver. 2009. "On Analytic Theology." In Analytic Theology: New Essays in the Philosophy of Theology, edited by Oliver D. Crisp and Michael C. Rea. Oxford University Press. 66.

. 2017. "Analytic Theology as Systematic Theology." Open Theology 3: 156-

Kierkegaard, Søren. 1997. Concluding Unscientific Postscript to Philosophical Fragments. Volume 1, edited and translated by Howard V. and Edna H. Hong. Princeton University Press.

McCall, Thomas M. 2015. An Invitation to Christian Analytic Theology. IVP Academic.

Plantinga, Alvin. 1992. "Augustinian Christian Philosophy." The Monist 75: 291-320. . 1997. "Ad Hick," Faith and Philosophy 14: 295-98.

. 2000. "Pluralism: A Defense of Religious Exclusivism." In The Philosophical Challenge of Religious Diversity, edited by K. Meeker and Philip Quinn. Oxford University Press. 
Rea, Michael. 2009. "Introduction." In Analytic Theology: New Essays in the Philosophy of Theology, edited by Oliver D. Crisp and Michael C. Rea. Oxford University Press.

Stump, Eleonore. 2013. "Athens and Jerusalem: The Relationship of Philosophy and Theology." Journal of Analytic Theology 1: 45-59.

Webster, John. 2005. Confessing God: Essays in Christian Dogmatics. T \& T Clark. 2015. "What Makes Theology Theological?" Journal of Analytic Theology 3: $17-28$.

Wolterstorff, Nicholas. 2005. "To Theologians: From One Who Cares about Theology but is Not One of You." Theological Education 40: 79-92.

. 2009. "How Philosophical Theology Became Possible within the Analytic Tradition of Philosophy." In Analytic Theology: New Essays in the Philosophy of Theology, edited by Oliver D. Crisp and Michael C. Rea. Oxford University Press.

Wood, William. 2013. "Philosophical Theology in the Religious Studies Academy: Some Questions for Analytic Theologians." Journal of the American Academy of Religion 81: 592-600.

. 2014. "Analytic Theology as a Way of Life." Journal of Analytic Theology 2: 43-60.

. 2016. "Trajectories, Traditions, and Tools in Analytic Theology." Journal of Analytic Theology 4: 254-66. 